\title{
Pengaruh Komitmen Organisasional, Locus of Control, dan Posisi Auditor terhadap Penerimaan Perilaku Disfungsional Audit
}

(Studi Kasus pada Kantor Akuntan Publik di Kota Semarang)

\author{
HERMAWAN TRIONO \\ Universitas Dian Nuswantoro Semarang \\ Jl. Imam Bonjol No.207 Semarang 50131 \\ Email: hermawantriono0706@gmail.com
}

Diterima 26 Agustus 2020; disetujui 9 September 2020;

\begin{abstract}
This study aims to analyze whether the organizational commitment, locus of control, and auditor's position affect the acceptance of dysfunctional audit behavior. The population of this study are 100 independent auditors who work at Public Accountant Office on Semarang. Meanwhile, the sample of this research are 80 auditors. The Data were collected through questionnaire and analyzed using path analysis technique. The result indicates that there is positive influence of locus of control on acceptance of dysfuctional audit behavior, negative influence of auditor's position on acceptance of dysfunctional audit behavior, and negative influence of organizational commitment on acceptance of dysfunctional audit behavior.
\end{abstract}

Keywords: organizational commitment, locus of control, auditor's position, acceptance of dysfunctional audit behavior, path analysis

\section{PENDAHULUAN}

Latar Belakang. Tujuan audit atas laporan keuangan oleh auditor independen pada umumnya adalah untuk menyatakan pendapat tentang kewajaran laporan keuangan perusahaan yang diaudit. Pendapat auditor mengenai kewajaran laporan keuangan yang diaudit didasarkan atas evaluasi terhadap bukti-bukti audit yang diperoleh melalui pelaksanaan serangkaian prosedur audit. Hal ini sesuai dengan standar pekerjaan lapangan butir ketiga yang menyatakan "bukti audit kompeten yang cukup harus diperoleh melalui inspeksi, pengamatan, permintaan keterangan, dan konfirmasi sebagai dasar memadai untuk menyatakan pendapat atas laporan keuangan yang diaudit" (IAI 2017, ISA 530.5 ).

Kepercayaan para pemakai laporan keuangan auditan terhadap profesi akuntan publik sangat bergantung pada kualitas audit yang dihasilkan KAP. Kualitas audit adalah probabilitas seorang auditor untuk menemukan dan melaporkan kekeliruan, serta ketidakberesan yang terjadi dalam laporan keuangan yang diaudit (DeAngelo, 1980). Probabilitas auditor menemukan kekeliruan dan ketidakberesan dalam laporan keuangan yang diaudit dipengaruhi 
oleh kemampuan teknis auditor (seperti: pendidikan, pengalaman, profesionalisme), independensi, dan perilaku auditor dalam pelaksanaan program audit (DeAngelo, 1980; Raghunathan, 1991).

Perilaku auditor dalam pelaksanaan program audit merupakan faktor penting yang berpengaruh terhadap kualitas audit yang dihasilkan KAP (Raghunathan, 1991; Kelley dan Margheim, 1990; Malone dan Robert, 1996). Pelaksanaan prosedur audit secara cermat dan seksama sebagaimana digariskan dalam program audit, membantu KAP untuk dapat menghasilkan jasa audit yang berkualitas (McDaniel, 1990; Malone dan Robert, 1996).

Perilaku disfungsional audit adalah setiap tindakan yang dilakukan auditor dalam pelaksanaan program audit yang dapat mereduksi atau menurunkan kualitas audit secara langsung maupun tidak langsung (Kelley dan Margheim, 1990; Otley dan Pierce, 1996). Tindakan-tindakan yang dilakukan auditor dalam pelaksanaan program audit yang dapat mereduksi kualitas audit secara langsung disebut sebagai perilaku reduksi kualitas audit (audit quality reduction behaviors). Faktor pendorong perilaku audit tersebut bermacammacam, salah satunya adalah posisi auditor.

Pada umumnya struktur organisasi KAP disusun secara hirarkis dengan susunan sebagai berikut: junior, senior, supervisor, manajer, dan partner (Setiawan dan Ghozali, 2006). Bila diperbandingkan dengan posisi individual pada struktur organisasi bisnis, auditor junior dan senior setara dengan karyawan yang menduduki posisi level bawah, sedangkan auditor supervisor, manajer, dan partner setara dengan manajer level menengah dan puncak (McNair, 1991; Otley dan Pierce, 1996; Jusup, 2001). Posisi auditor pada hirarki organisasi KAP menggambarkan tugas, kewenangan dan tanggungjawab individu auditor di KAP. Auditor junior dan senior melaksanakan sebagian besar prosedur audit, dan kinerja mereka disupervisi oleh auditor pada posisi yang lebih tinggi (McNair, 1991).

Faktor berikutnya adalah locus of control, yaitu karakteristik personalitas yang menggambarkan tingkat keyakinan seseorang tentang sejauh mana mereka dapat mengendalikan faktor-faktor yang mempengaruhi keberhasilan atau kegagalan yang dialaminya (Rotter, 1966). Seseorang yang meyakini keberhasilan atau kegagalan yang dialaminya berada dalam kontrolnya disebut memiliki locus of control internal, pada pihak lain individu yang meyakini keberhasilan atau kegagalan yang dialaminya ditentukan oleh faktor-faktor eksternal (di luar kontrolnya) disebut memiliki locus of control eksternal (Lefcourt, 1982).

Karakteristik individual auditor berikutnya yang dikaji pada penelitian ini adalah komitmen auditor terhadap organisasinya. Komitmen organisasional adalah suatu keadaan dimana seorang auditor memihak pada suatu organisasi tertentu dan tujuantujuannya, serta berniat memelihara keanggotaan dalam organisasi itu (Robbins, 2003). Auditor yang memiliki komitmen organisasional akan memiliki tingkat loyalitas yang lebih baik. Auditor yang loyal terhadap organisasi memiliki keyakinan atas tujuan dan nilai-nilai organisasi. Berdasarkan pada keyakinan tersebut, maka auditor yang memiliki komitmen organisasional tinggi bersedia melakukan pekerjaan melebihi apa yang seharusnya dikerjakan (Irawati dkk., 2005). Loyalitas yang tinggi akan mengakibatkan auditor cenderung tidak menerima perilaku disfungsional audit daripada auditor yang memiliki komitmen organisasional yang rendah (Malone dan Roberts, 1996). 
Penelitian ini dilakukan untuk mengetahui faktor yang berkontribusi terhadap perbedaan auditor secara individu dalam sikap terhadap perilaku disfungsional audit. Mendapatkan pemahaman tentang faktor penyebab tersebut sejalan dengan proses yang diuraikan dalam Statement on Auditing Standarts (SAS) No. 82 yang mengharuskan auditor untuk melihat manajemen sikap terhadap salah saji dan penipuan pelaporan sebagai indikator penipuan laporan keuangan yang sebenarnya (AICPA 1997).

Tujuan Penelitian. Tujuan dari penelitian ini adalah untuk mengetahui apakah terdapat hubungan antara locus of control dan posisi auditor dengan komitmen organisasional dan untuk mengetahui apakah terdapat hubungan antara locus of control, posisi auditor, dan komitmen organisasi dengan penerimaan perilaku disfungsional audit.

\section{TINJAUAN TEORETIS}

Locus of Control. Locus of control merupakan karakteristik individual yang menunjukkan tingkat keyakinan seseorang tentang faktor-faktor yang berpengaruh atas keberhasilan atau kegagalan yang mereka alami (Lefcourt, 1982). Seseorang yang meyakini keberhasilan atau kegagalan yang dialaminya berada dalam kontrolnya disebut memiliki locus of control internal, sebaliknya individu yang meyakini keberhasilan atau kegagalan yang dihadapinya ditentukan oleh faktor-faktor eksternal (di luar kontrolnya) disebut memiliki locus of control eksternal (Lefcourt, 1982). Setiap individu memiliki locus of control tertentu yang berada di antara kedua ekstrim tersebut.

Hubungan Locus of Control dengan Komitmen Organisasi. Berbagai penelitian menunjukkan hubungan locus of control dengan komitmen organisasional. Hyatt dan Prawitt (2001) memberikan bukti bahwa seseorang dengan locus of control internal akan memiliki kinerja yang tinggi. Dengan demikian dikarenakan sifat teknis dan profesionalisme dari lingkungan pekerjaan auditor, maka seseorang dengan locus of control internal akan memiliki kinerja yang lebih tinggi dibanding seseorang dengan locus of control eksternal. Penelitian yang dilakukan oleh Luthans et al. (1987) dan Kinicki dan Vecchio (1994) menemukan bahwa locus of control merupakan faktor (anteseden) terjadinya komitmen organisasional. Sehingga, auditor dengan locus of control internal cenderung akan lebih memiliki komitmen yang lebih tinggi dibanding auditor dengan locus of control eksternal. Dengan demikian, dapat dihipotesiskan:

H1 : Locus of control eksternal berpengaruh negatif terhadap komitmen organisasional.

\section{Hubungan Locus of Control dan} Perilaku Disfungsional Audit. Hasil review yang dilakukan oleh Loe et al. (2000) atas berbagai hasil penelitian (Hegarty dan Sims, 1978; Singapakdi dan Vitell, 1990) menunjukkan bahwa dalam pembuatan keputusan etis, peran locus of control berbeda-beda. Hasil penelitian Zahra (1989) menunjukkan manajer dengan locus of control eksternal menganggap bahwa kebijakan organisasi sebagai sesuatu yang etis. Hasil penelitian Trevino dan Youngblood (1990) menemukan bahwa locus of control mempengaruhi pembuatan keputusan etis yang dilakukan seseorang secara langsung atau tidak langsung. Beu dan Buckley (2001) menghipotesiskan bahwa seseorang dengan locus of control internal lebih sering memiliki perilaku etis dibanding seseorang dengan locus of control eksternal. 
Dalam konteks audit, manipulasi atau penipuan mencerminkan bentuk penyimpangan dalam penugasan audit. Bagi auditor, perilaku semacam ini berarti memanipulasi proses audit demi tujuan kepentingan auditor secara pribadi (Donnelly et al., 2003). Hasil penelitian Donnelly et al. (2003) menunjukkan bahwa semakin tinggi locus of control eksternal seorang auditor, semakin besar kemungkinan terjadinya perilaku disfungsional audit. Dengan demikian, dapat dihipotesiskan:

$\mathrm{H} 2$ : Locus of control eksternal berpengaruh positif terhadap perilaku disfungsional audit.

Hubungan Posisi Auditor di KAP dan Komitmen Organisasional. Beberapa penelitian sebelumnya telah meneliti hubungan antara masa jabatan dalam organisasi dan komitmen organisasional, didasarkan pada premis bahwa seseorang berkomitmen terhadap organisasi sebagai hasil dari akumulasi investasi yang telah mereka lakukan dalam organisasi (Becker 1960). Seiring berjalannya waktu, seseorang mengakumulasi investasi yang lebih besar dan dengan demikian menjadi lebih berkomitmen kepada organisasi. Dalam penelitian sebelumnya, masa jabatan dalam organisasi digunakan sebagai ukuran pengganti dari akumulasi investasi seseorang, dan ditemukan berhubungan dengan komitmen organisasional secara signifikan (Alutto et al., 1973; Farrell dan Rusbult, 1981; Meyer dan Allen, 1984). Menggunakan meta-analisis dari 25 sampel didasarkan pada penelitian sebelumnya, Mathieu dan Zajac (1990) menemukan bahwa, masa jabatan dalam organisasi berkorelasi positif dengan komitmen organisasional.

Dalam penelitian sebelumnya, hipotesis bahwa masa jabatan dalam organisasi tercermin dalam poisisi seseorang dalam organisasi, yang akan berpengaruh secara positif dengan komitmen organisasional. Dengan demikian, dapat dihipotesiskan:

H3 : Posisi berpengaruh postif terhadap komitmen organisasional.

Hubungan Posisi Auditor di KAP dan Perilaku Disfungsional Audit. Posisi seseorang dalam organisasi telah dikaitkan dengan perilaku disfungsional di lingkungan audit. Kelley dan Seiler (1982) menemukan bahwa underreporting of time lebih sering dilakukan oleh auditor senior dan junior. Demikian pula, Alderman dan Deitrick (1982) mensurvei seluruh tingkatan jabatan audit dalam suatu perusahaan sehubungan dengan terjadinya premature sign off dalam audit, dan ditemukan perbedaan yang signifikan berdasarkan posisi dalam perusahaan. Dampak negatif dari perilaku disfungsional audit terhadap kualitas audit yang digabungkan dengan hirarki dalam organisasi yang ada dalam profesi akuntansi menunjukkan bahwa auditor yang berada di posisi atas akan kurang menerima perilaku disfungsional audit. Auditor dengan posisi di atas akan lebih mengenali efek buruk dari perilaku disfungsional. Mereka diharapkan lebih tertarik untuk menyediakan jasa yang berkualitas bagi perusahaan dan menciptakan citra yang baik bagi perusahaan. Sehingga, dapat dihipotesiskan:

H4 : Posisi berpengaruh negatif terhadap perilaku disfungsional audit.

\section{Hubungan Komitmen Organisasional} dan Perilaku Disfungsional Audit. Beberapa penelitian terdahulu menunjukkan bahwa komitmen organisasional bertindak sebagai ukuran dari identifikasi karyawan dengan organisasi (Hollinger dan Clark, 1983). Ada 3 faktor yang secara tradional digunakan untuk mengkarakterisasi konstruksi komitmen : keyakinan yang kuat dan penerimaan nilai organisasi, keinginan bekerja keras untuk mencapai tujuan organisasi, dan keinginan untuk memper- 
tahankan keanggotaan dalam organisasi (Mowday et al., 1982). Komitmen organisasional dikaitkan dengan perilaku positif, seperti kinerja pekerjaan dan kehadiran (Porter et al., 1974). Komitmen organisasional juga dikaitkan dengan perilaku disfungsional, seperti resistensi untuk berubah dan keengganan untuk meninggalkan karena kurangnya kemampuan (Aranya dan Ferris, 1984).

Akibatnya, komitmen organisasional menciptakan kekuatan untuk menyeimbangkan kecenderungan disfungsional. Seiring dengan peningkatan komitmen, organisasi tidak dipandang sebagai musuh dan manipulasi tidak diperlukan untuk mendapatkan yang diinginkan. Seseorang yang memiliki keyakinan kuat terhadap organisasi dan bersedia untuk bekerja keras untuk mencapai tujuan organisasi, akan kurang menerima perilaku disfungsional untuk mencapai tujuan pribadi.

Peran penting dari komitmen organisasional dapat pula mencerminkan perbedaan dalam motivasi antara individu yang memiliki komitmen organisasi tinggi dengan yang rendah (Nouri dan Parker, 1996). Lincoln dan Kalleberg (1990) berpendapat, karyawan yang berkomitmen tinggi akan mengupayakan demi organisasi, walaupun upaya tersebut tidak langsung berkontribusi kepada kompensasi individu atau peluang karir. Seseorang dengan komitmen organisasional yang tinggi ingin organisasi menjadi sukses. Apabila individu tersebut memandang beberapa perilaku sebagai perilaku perilaku disfungsional, individu tersebut akan kurang menerima aktivitas tersebut. Seseorang dengan komitmen organisasional yang rendah, mungkin akan lebih tertarik untuk mengejar kepentingan pribadinya dibandingkan kepentingan organisasi. Dengan demikian, seseorang yang memiliki komitmen organisasional yang rendah lebih cenderung untuk melihat perilaku disfungsional sebagai sesuatu yang dapat diterima, demi kepentingan pribadi (seperti, underreporting of time). Dengan demikian, dapat dihipotesiskan :

H5 : Ada hubungan negatif antara komitmen organisasional terhadap perilaku disfungsional audit.

Kerangka Pikir Teoritis. Berdasarkan landasan teori di atas, maka hubungan antar variabel pada penelitian ini dapat digambarkan pada Gambar 1.

\section{Gambar 1}

\section{Kerangka Pikir Teoritis}

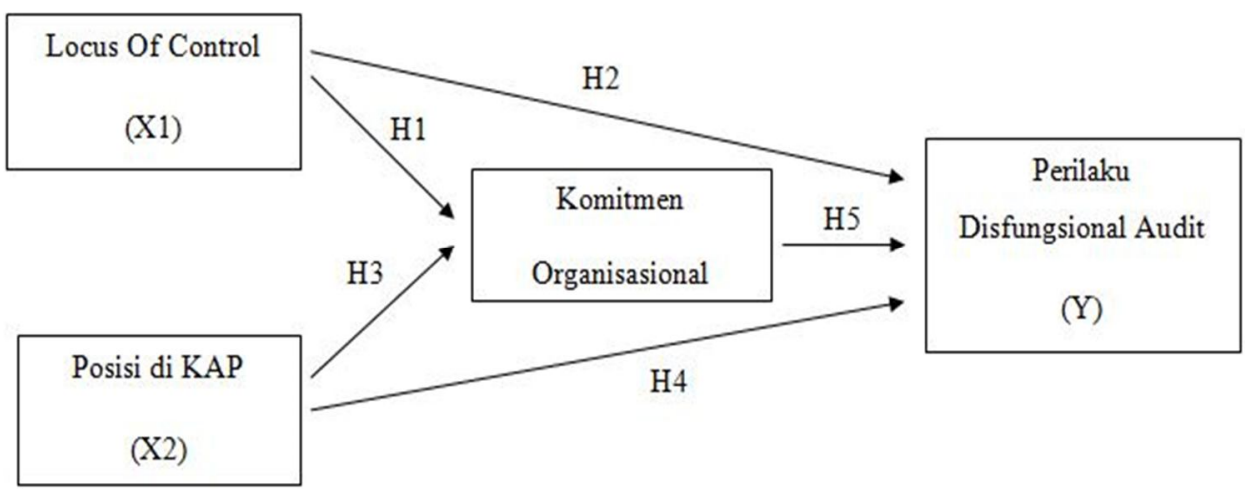




\section{METODE PENELITIAN}

Populasi dan Sampel. Populasi dalam penelitian ini adalah semua auditor yang bekerja di Kantor Akuntan Publik kota Semarang yang berjumlah 100 orang. Dalam penelitian ini, penulis menggunakan tekhnik pengambilan sampel menggunakan metode probability sampling, yaitu tekhnik sampling yang memberikan peluang yang sama bagi setiap unsur (anggota) populasi untuk dipilih menjadi anggota sampel.

Definisi Operasional dan Pengukuran Variabel. Berikut ini merupakan definisi operasional dan pengukuran untuk masingmasing variabel dalam penelitian ini:

\section{Perilaku Disfungsional Audit}

Perilaku disfungsional audit adalah setiap tindakan yang dilakukan auditor selama pelaksanaan program audit yang dapat mereduksi kualitas audit baik secara langsung maupun tidak langsung (Kelley dan Margheim, 1990; Otley dan Pierce, 1996). Variabel ini diukur menggunakan instrumen yang dibuat oleh Donelly et al. (2003). Instrumen variabel ini terdiri dari 12 butir pertanyaan yang dijawab dengan menggunakan skala Likert 1 sampai 7 poin. Jawaban dari responden digunakan untuk menentukan tingkat penerimaan perilaku disfungsional audit, yaitu penerimaan perilaku disfungsional audit yang rendah untuk jawaban pada skala rendah dan sebaliknya penerimaan perilaku disfungsional audit untuk jawaban pada skala tinggi.

\section{Locus Of Control}

Locus of control adalah cara pandang seseorang terhadap suatu peristiwa apakah dia merasa dapat atau tidak dapat mengendalikan peristiwa yang terjadi padanya (Rotter, 1966). Teori locus of control menggolongkan individu apakah termasuk dalam locus internal atau eksternal.
Pengukuran locus of control individu auditor dilakukan dengan mengadopsi instrumen locus of control dari Donnelly et al., (2003). Instrumen ini terdiri 16 butir pertanyaan dengan menggunakan skala Likert 1 sampai 7 poin. Delapan butir pertanyaan disusun dengan skor terbalik yaitu pertanyaan nomor 1, 2, 3, 4, 7, 11, 14, dan 15. Skor yang lebih tinggi pada skala pengukuran mengindikasikan locus of control eksternal dan skor yang lebih rendah mengindikasikan locus of control internal. Pada butir pertanyaan dengan skor terbalik, skor yang tinggi pada skala pengukuran mengindikasikan locus of control internal, sedangkan skor yang rendah mengindikasikan locus of control eksternal.

\section{Posisi Auditor di KAP}

Posisi auditor pada KAP yang dimaksud pada penelitian ini adalah kedudukan auditor pada hirarki organisasi KAP yaitu junior, senior, supervisor, manajer, dan partner. Posisi junior auditor, diberi nilai 0 dan seterusnya.

\section{Komitmen Organisasional}

Cut Zurnali (2010) mendefinisikan pengertian komitmen organisasional sebagai sebuah keadaan psikologi yang mengkarakteristikkan hubungan karyawan dengan organisasi atau implikasinya yang mempengaruhi apakah karyawan akan tetap bertahan dalam organisasi atau tidak. Pengukuran komitmen organisasional individu auditor dilakukan dengan mengadopsi instrumen dari Donnelly et al., (2003). Instrumen variabel ini terdiri dari 9 butir pertanyaan yang dijawab dengan menggunakan skala Likert 1 sampai 7 poin. Skor yang tinggi pada skala pengukuran mengindikasikan komitmen pada level yang lebih tinggi, sebaliknya skor yang rendah mengindikasikan komitmen pada level yang lebih rendah. 
Teknik Analisis: Path Analysis. Model path analysis (analisis jalur) merupakan perluasan dari analisis regresi linier berganda atau analisis jalur adalah penggunaan analisis regresi untuk menaksir hubungan kausalitas antara variabel (model causal) yang telah ditetapkan sebelumnya berdasarkan teori (Ghozali, 2011). Analisis jalur digunakan untuk menganalisis pola hubungan antar variabel, dengan tujuan untuk mengetahui pengaruh langsung maupun tidak langsung seperangkat variabel independen (eksogen) terhadap variabel dependen (endogen).

\section{HASIL DAN PEMBAHASAN}

Hasil Path Analysis. Dari hasil pengolahan data terlihat nilai standardized beta locus of control pada persamaan (1) sebesar -0.549 dan signifikan di angka 0.000 berarti locus of control terkait secara negatif dengan komitmen organisasional yang menyiratkan bahwa seseorang yang mempunyai locus of control internal mempunyai level komitmen organisasional yang lebih tinggi dibandingkan eksternal. Nilai koefisien regresi untuk variabel locus of control terhadap variabel komitmen organisasional menunjukkan nilai parameter yang negatif yaitu sebesar -0.549 , hal ini menunjukkan apabila locus of control eksternal seseorang meningkat maka komitmen organisasionalnya akan menurun.

Berbagai penelitian menunjukkan hubungan locus of control dengan komitmen organisasional. Hyatt dan Prawitt (2001) memberikan bukti bahwa seseorang dengan locus of control internal akan memiliki kinerja yang tinggi. Dengan demikian dikarenakan sifat teknis dan profesionalisme dari lingkungan pekerjaan auditor, maka seseorang dengan locus of control internal akan memiliki kinerja yang lebih tinggi dibanding seseorang dengan locus of control eksternal. Penelitian yang dilakukan oleh Luthans et al. (1987) dan Kinicki dan Vecchio (1994) menemukan bahwa locus of control merupakan faktor terjadinya komitmen organisasional. Hasil penelitian yang dilakukan oleh Donelly et al, (2003) juga menunjukkan bahwa locus of control berpengaruh negatif terhadap komitmen organisasional. Hal ini sesuai dengan hipotesis 1 yang menyatakan bahwa locus of control eksternal berpengaruh negatif terhadap komitmen organisasional.

Gambar 2

Hasil Uji Path Analysis

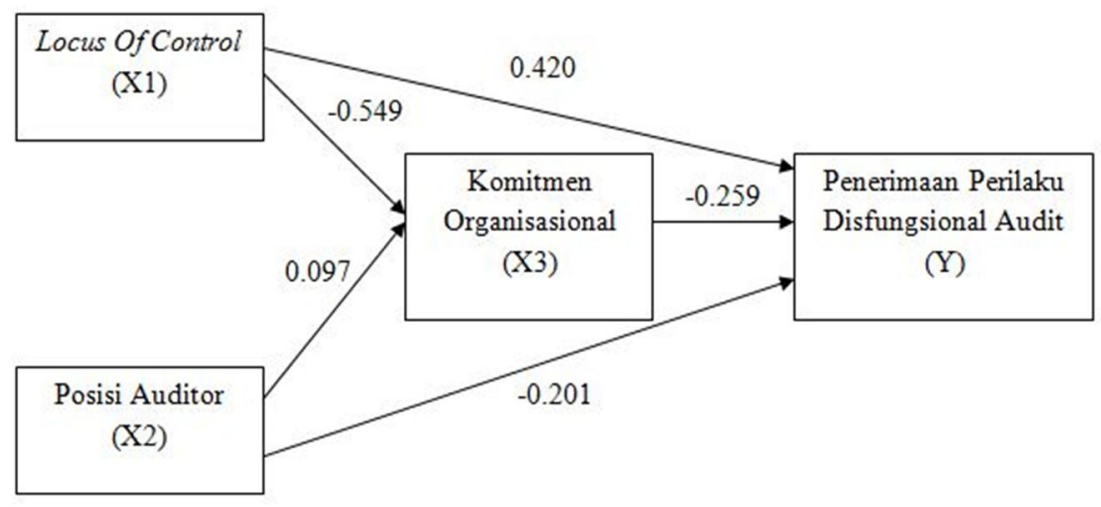


Nilai standardized beta locus of control pada persamaan (2) sebesar 0.420 dan signifikan di angka 0.000 yang berarti secara langsung, locus of control berpengaruh positif dan signifikan terhadap penerimaan perilaku disfungsional audit. Besar pengaruh langsung locus of control terhadap penerimaan perilaku disfungsional audit adalah sebesar 0.420 yaitu 42 persen. Artinya, tinggi rendahnya penerimaan perilaku disfungsional audit dipengaruhi oleh locus of control sebesar 42 persen sedangkan sisanya 58 persen dipengaruhi faktor lain di luar model. Nilai koefisien regresi untuk variabel locus of control terhadap variabel penerimaan perilaku disfungsional audit menunjukkan nilai parameter yang positif yaitu sebesar 0.420 , hal ini menunjukkan apabila locus of control eksternal seseorang meningkat maka penerimaan perilaku disfungsional audit juga akan meningkat.

Hasil review yang dilakukan oleh Loe et al. (2000) atas berbagai hasil penelitian (Hegarty dan Sims, 1978; Singapakdi dan Vitell, 1990) menunjukkan bahwa dalam pembuatan keputusan etis, peran locus of control berbeda-beda. Hasil penelitian Zahra (1989) menunjukkan manajer dengan locus of control eksternal menganggap bahwa kebijakan organisasi sebagai sesuatu yang etis. Hasil penelitian Trevino dan Youngblood (1990) menemukan bahwa locus of control mempengaruhi pembuatan keputusan etis yang dilakukan seseorang secara langsung atau tidak langsung. Beu dan Buckley (2001) menghipotesiskan bahwa seseorang dengan locus of control internal lebih sering memiliki perilaku etis dibanding seseorang dengan locus of control eksternal. Dalam konteks audit, manipulasi atau penipuan mencerminkan bentuk penyimpangan dalam penugasan audit. Bagi auditor, perilaku semacam ini berarti memanipulasi proses audit demi tujuan kepentingan auditor secara pribadi (Donnelly et al., 2003). Hasil penelitian Donnelly et al. (2003) menunjukkan bahwa semakin tinggi locus of control eksternal seorang auditor, semakin besar kemungkinan terjadinya perilaku disfungsional audit. Sehingga, hipotesis 2 yang menyatakan bahwa ada hubungan positif antara locus of control eksternal terhadap perilaku disfungsional audit, diterima.

Nilai standardized beta posisi auditor pada persamaan (1) sebesar 0.097 tetapi tidak signifikan (nilai signifikan 0.324) berarti posisi auditor tidak mempengaruhi komitmen organisasional. Sehingga, hipotesis 3 yang menyatakan bahwa posisi berpengaruh positif terhadap komitmen organisasional, ditolak.

Penelitian sebelumnya telah meneliti hubungan antara masa jabatan dalam organisasi dan komitmen organisasional, didasarkan pada premis bahwa seseorang berkomitmen terhadap organisasi sebagai hasil dari akumulasi investasi yang telah mereka lakukan dalam organisasi (Becker 1960). Masa jabatan dalam organisasi digunakan sebagai ukuran pengganti dari akumulasi investasi seseorang, dan ditemukan berhubungan dengan komitmen organisasional secara signifikan (Alutto et al., 1973; Farrell dan Rusbult, 1981; Meyer dan Allen, 1984). Dalam penelitian sebelumnya, hipotesis bahwa masa jabatan dalam organisasi tercermin dalam poisisi seseorang dalam organisasi, yang akan berpengaruh secara positif dengan komitmen organisasional. Namun teori ini tidak sesuai dengan hasil penelitian yang telah dilakukan. Hasil penelitian menunjukkan bahwa posisi auditor tidak mempunyai pengaruh terhadap komitmen organisasional. Hal ini mungkin disebabkan kurangnya etos kerja dari 
seorang auditor atau masih kurangnya pemahaman terhadap akibat dari perilaku disfungsional audit. Hal ini masih memerlukan penelitian yang lebih mendalam.

Nilai standardized beta posisi auditor pada persamaan (2) sebesar -0.201 dan signifikan pada 0.028 yang berarti posisi auditor mempunyai hubungan negatif dengan penerimaan perilaku disfungsional audit. Nilai koefisien regresi untuk variabel posisi auditor terhadap variabel penerimaan perilaku disfungsional audit menunjukkan nilai parameter yang negatif yaitu sebesar 0.201, hal ini menunjukkan apabila posisi auditor naik maka penerimaan perilaku disfungsional audit akan menurun.

Posisi seseorang dalam organisasi telah dikaitkan dengan perilaku disfungsional di lingkungan audit. Kelley dan Seiler (1982) menemukan bahwa underreporting of time lebih sering dilakukan oleh auditor senior dan junior. Demikian pula, Alderman dan Deitrick (1982) mensurvei seluruh tingkatan jabatan audit dalam suatu perusahaan sehubungan dengan terjadinya premature sign off dalam audit, dan ditemukan perbedaan yang signifikan berdasarkan posisi dalam perusahaan. Dampak negatif dari perilaku disfungsional audit terhadap kualitas audit yang digabungkan dengan hirarki dalam organisasi yang ada dalam profesi akuntansi menunjukkan bahwa auditor yang berada di posisi atas akan kurang menerima perilaku disfungsional audit. Hal ini mendukung hipotesis 4 yang menyatakan bahwa, posisi berpengaruh negatif terhadap perilaku disfungsional audit dan menyarankan agar karyawan yang berada di posisi tinggi dalam perusahaan untuk kurang menunjukkan penerimaan perilaku disfungsional audit.

Nilai standardized beta komitmen organisasional pada persamaan (2) sebesar 0.259 dan signifikan pada 0.019 yang berarti komitmen organisasional berpengaruh terhadap penerimaan perilaku disfungsional audit. Nilai koefisien regresi untuk variabel komitmen organisasional terhadap variabel penerimaan perilaku disfungsional audit menunjukkan nilai parameter yang negatif yaitu sebesar -0.259 , hal ini menunjukkan apabila komitmen organisasional seseorang naik maka penerimaan perilaku disfungsional audit akan menurun.

Penelitian terdahulu menunjukkan bahwa komitmen organisasional bertindak sebagai ukuran dari identifikasi karyawan dengan organisasi (Hollinger dan Clark, 1983). Komitmen organisasional dikaitkan dengan perilaku positif, seperti kinerja pekerjaan dan kehadiran (Porte et al., 1974). Komitmen organisasional juga dikaitkan dengan perilaku disfungsional, seperti resistensi untuk berubah dan keengganan untuk meninggalkan karena kurangnya kemampuan (Aranya dan Ferris, 1984). Komitmen organisasional menciptakan kekuatan untuk menyeimbangkan kecenderungan disfungsional.

Peran penting dari komitmen organisasional dapat pula mencerminkan perbedaan dalam motivasi antara individu yang memiliki komitmen organisasi tinggi dengan yang rendah (Nouri dan Parker, 1996). Lincoln dan Kalleberg (1990) berpendapat, karyawan yang berkomitmen tinggi akan mengupayakan demi organisasi, walaupun upaya tersebut tidak langsung berkontribusi kepada kompensasi individu atau peluang karir. Hal ini sesuai dengan hipotesis 5 yang menyatakan bahwa, ada hubungan negatif antara komitmen organisasional terhadap perilaku disfungsional audit. Dengan demikian, seorang karyawan yang memiliki level komitmen organisasional yang tinggi akan kurang menerima perilaku disfungsional audit. 


\section{SIMPULAN}

Kesimpulan. Berdasarkan penelitian yang telah dilakukan maka dapat diperoleh kesimpulan sebagai berikut:

1. Locus of control berpengaruh negatif dan signifikan terhadap komitmen organisasional, dengan demikian hipotesis pertama dapat diterima.

2. Locus of control berpengaruh positif dan signifikan terhadap penerimaan perilaku disfungsional audit, dengan demikian hipotesis kedua dapat diterima.

3. Posisi auditor mempunyai hasil yang positif namun tidak signifikan terhadap komitmen organisasional, dengan demikian hipotesis ketiga ditolak.

4. Posisi auditor berpengaruh secara negatif dan signifikan terhadap penerimaan perilaku disfungsional audit, dengan demikian hipotesis keempat dapat diterima.

5. Komitmen organisasional berpengaruh secara negatif dan signifikan terhadap penerimaan perilaku disfungsional audit, dengan demikian hipotesis kelima dapat diterima.

6. Locus of control, posisi auditor, dan komitmen organisasional mempunyai pengaruh yang signifikan terhadap penerimaan perilaku disfungsional audit.

Saran. Setelah menarik kesimpulan dari hasil penelitian, maka diajukan saran sebagai berikut:

1. Kantor Akuntan Publik perlu untuk memberikan training dan pengenalan budaya perusahaan kepada staffnya, terutama auditor pada posisi level bawah.

2. Kantor Akuntan Publik perlu mengevaluasi kebijakan yang dapat dilakukan untuk mengatasi kemungkinan terjadinya praktek perilaku disfungsional audit. Kebijakan tersebut dapat berupa perencanaan jenis prosedur yang tepat, mem- berikan kompensasi dan promosi, memberi pengarahan untuk memberikan hasil pekerjaan yang berkualitas, tidak hanya memenuhi batas waktu, serta kontrol kualitas yang efektif dalam Kantor Akuntan Publik.

\section{DAFTAR PUSTAKA}

Akers, M. D. and Eaton, T. V. 2003. "Underreporting of Chargeable Time: The Impact of Gender and Characteristic of Underreporters". Journal of Managerial Issues. Volume XV No. 1. pp. 82-89.

Alderman, C. W. and Deitrick, J. W. 1982. "Auditor's Perceptions of Time Budget Pressure and Premature Sign-offs: A Replication and Extension". Auditing: A Journal of Practice and Theory. Volume 1 No. 2. pp. 54-58.

Allen, N. J. and Meyer, J. P. 1993. "Organizational Commitment: Evidence of Career Stage Effects?". Journal of Business Research. Volume 26. pp. 49-61.

Alutto, J. A., Hrebiniak, L. G., and Alonso, R. C. 1973. "On Operationalizing the Concept of Commitment". Social Forces. Volume 51. pp. 448-454.

American Institute of Certified Public Accountants. 1997. Consideration of Fraud in a Financial Statement Audit. Statement on Auditing Standards No. 82. New York.

Aranya, N. And Ferris, K. R. 1984. "An Examination of Accountants' Organizational-Professional Conflict". The Accounting Review. January. pp. 115.

Arikunto, Suharsimi. 2006. Prosedur Penelitian Suatu Pendekatan Praktik. Jakarta: Rineka Cipta.

Basuki dan Mahardani, Y. K. 2006. "Pengaruh Tekanan Anggaran Waktu Terhadap Perilaku Disfungsional Auditor dan Kualitas Audit pada Kantor Akuntan Publik di Surabaya". Jurnal Maksi. Volume 6 No. 2. pp. 203-223. 
Becker, H. S. 1960. "Notes on the Concept of Commitment". American Journal of Sociology. Volume 66. pp. 32-40.

Beu, D. and Buckley, M. R. 2001. "The Hypothesized Relationship Between Accountability and Ethical Behavior". Journal of Business Ethics. Volume 34. pp. 57-73.

Cook, E. and Kelley, T. 1988. "Auditor Stress and Time Budgets". The CPA Journal. Volume 58 No. 7. pp. 83-86.

Coram, P., Ng, Juliana., and Woodliff, D. 2003. "A Survey of Time Budget Pressure and Reduced Audit Quality Among Australian Auditors". Australian Accounting Review. Volume 13 No. 1. pp. 38-45.

Cut Zurnali, 2010. "Learning Organization, Competency, Organizational Commitment, and Customer Orientation: Knowledge Worker - Kerangka Riset Manajemen Sumberdaya Manusia di Masa Depan". Bandung: Unpad Press.

DeAngelo, L. E. 1981. "Auditor Size and Auditor Quality". Journal of Accounting and Economics. Volume 3 No. 3. pp. 183199.

Dirsmith, M. and Covaleski, M. 1985. "Informal Communications, Nonformal Communications, and Mentoring in Public Accounting". Accounting Organization and Society. Volume 10 No. 2. pp. 149-169.

Donnely, David P., Quirin, Jeffrey J., and O'Bryan, D. 2003a. "Auditor Acceptance of Dysfunctional Audit Behavior: An Explanatory Model Using Auditor's Personal Characteristics". Behavioral Research In Accounting. Volume 15. pp. 87-110. Dysfunctional Audit Behavior: The Effects Of Locus Of Control, Organizational Commitment, and Position". The Journal of Applied Business Research. Volume 19 No. 1. pp. 95-108.

Farrel, D. and Rusbult, C. E. 1981. "Exchange Variables as Predictors of Job
Satisfaction, Job Commitment, and Turnover: The Import of Rewards, Costs, Alternatives, and Investments," Organizational Behavior and Human Performance. Volume 27-28. pp. 78-95.

Fleming, M. K. 1980. "Budgeting Practices in Large CPA Firms". The Journal of Accountancy. May. pp. 55-62.

Ford, Robert C. and Rhicardson, D. 1994. "Ethical Decision Making: A Review Of The Empirical Literature". Journal of Business Ethics. Volume 13. pp. 205-221.

Ghozali, Imam. 2011. Aplikasi Analisis Multivariate dengan Program IBM SPSS 19. Edisi Lima. Semarang: UNDIP Press.

Gibson, J. L., Ivancevich, J. M., and Donnelly, J.

H. 1995. Organizations, Behaviours, Structure, Process. Eight Edition. Boston Massachusetts: Irwin.

Heriningsih, S. 2002. "Penghentian Prematur Atas Prosedur Audit: Sebuah Studi Empiris Pada Kantor Akuntan Publik". Wahana. Volume 2. pp. 111-122.

Herrbach, O. 2001. "Audit Quality, Auditor Behaviour and the Psychological Contract. European Accounting Review. Volume 10 No. 4. pp. 787-802.

Hollinger, R. And Clark, J. 1983. Theft by Employees. Lexington: Lexington Books.

Hyatt, T. and Prawitt, D. F. 2001. "Does Congruence Between Audit Structure and Auditors Locus of control Affect Job Performance". The Accounting Review. Volume 76 No. 2.

Indri, K. dan Wijayanti, P. 2007. "Locus Of Control sebagai Anteseden Hubungan Kinerja Pegawai dan Penerimaan Perilaku Disfungsional Audit". Simposium Nasional Akuntansi X. Makasar.

Indriantoro dan Supomo. 2002. Metodologi Penelitian Bisinis Untuk Akuntansi dan Manajemen. Edisi Pertama. Yogyakarta: Penerbit BPFE.

Ikatan Akuntan Indonesia. 2001. Standar Profesional Akuntan Publik. Jakarta: Salemba Empat.

Irawati, Y., Petrolina, A. T., dan Mukhlasin. 2005. "Hubungan Karakteristik Personal 
Auditor Terhadap Tingkat Penerimaan Penyimpangan Perilaku Dalam Audit". Simposium Nasional Akuntansi VIII. Solo.

Jusup, AL. H. 2001. Auditing (Pengauditan). Buku Satu Cetakan Pertama. Yogyakarta: STIE-YKPN.

Kelley, T. and Margheim, L. 1990. "The Impact of Time Budget Pressure, Personality and Leadership Variable on Dysfunctional Behavior". Auditing: A Journal of Practice and Theory. Volume 9. No. 2. pp. 21-41.

-----, and Seiler, R. E. 1982. "Auditor Stress and Time Budget". The CPA Journal. December. pp. 24-34.

Kinicki, A. J. and Vecchio, R. P. 1994. "Influences on the Quality of SupervisorSubordinate Relations: The Role of TimePressure, Organizational Commitment, and Locus Of Control". Journal of Organizational Behavior. Volume 15. pp. 75-82.

Kreitner, R. and Kinicki, A. 2000. Organizational Behavior. Fifth Edition. Mc Graw-Hill.

Lefcourt, H. 1982. Locus of Control: Current Trends in Theory and Research. Second Edition. Hillsdale: Lawrence Erlbaum.

Lestari, Ayu P. 2010. Faktor-Faktor yang Mempengaruhi Perilaku Auditor Dalam Penghentian Prematur Prosedur Audit. Skripsi. Semarang: Program Sarjana Universitas Diponegoro.

Lightner, S. S., Adams, S., and Lightner, K. 1982. "The Influence of Situational, Ethical and Expentancy Theory Variables on Accountants' Underreporting Behavior". Auditing: Journal of Practice and Theory. Volume 2. pp. 1-12.

Lincoln, J. And Kalleberg, A. 1990. Culture, Control, and Commitment. Cambridge: Cambridge University Press.

Loe, Terry W., Ferrel, L., and Mansfield, P. 2000. "A Review of Empirical Studies Assessing Ethical Decision Making In Business". Journal of Business Ethics. Volume 25. pp. 185-204.
Luthans, F., Baack, D., and Taylor, L. 1987. "Organizational Commitment: Analysis of Antecedents". Human Relations. Volume 40 No. 4.

Malone, C. F. and Robert, R. W. 1996. "Factors Associated With the Incidence of Reduced Audit Quality Behavior". Auditing: A Journal of Practice and Theory. Volume 15 No. 2. pp. 49-64.

Marxen, D. E. 1990. “A Behavioral Investigation of Time Budget Preparation in a Competitive Audit Environment". Accounting Horizon. June. pp. 47-57.

Mathieu, J. E. And Zajac, D. M. 1990. "A Review and Meta-Analysis of the Antecedents, Correlates, and Consequences of Organizational Commitment". Psychological Bulletin. Volume 108. pp. 171-194.

McDaniel, L. S. 1990. "The Effect of Time Pressure and Audit Program Structure on Audit Performance". Journal of Accountancy Research. Volume 28. pp. 267- 285.

McNair, C. J. 1991. "Proper Compromises: The Management Control Dilemma in Public Accounting and Its Impact on Auditor Behavior". Accounting, Organizations and Society. Volume 16 No. 7. pp. 635653.

Meyer, J. P. and Allen, N. J. 1984. "Testing the 'Side-Bet Theory' of Organizational Commitment: Some Methodological Considerations". Journal of Applied Psychology. Volume 69. pp. 372-378.

Mowday, R. T., Porter, L. W., and Steers, R. M. 1982. Employee-Organizational Linkages. New York: Academic Press.

Mulyadi. 2002. Auditing. Buku Satu Edisi Enam. Jakarta: Salemba Empat.

Nouri, H. and Parker, R. J. 1996. "The Effect of Organizational Commitment on the Relation Between Budgetary Participation and Budgetary Slack". Behavioral Research in Accounting. Volume 8. pp. 74-90.

Otley, D. T., and Pierce, B. J. 1996a. "Audit Time Budget Pressure: Consequence and 
Antecendents". Accounting, Auditing and Accountability Journal. Volume 9 No. 1. pp. 31-58.

--. 1996b. "The Operation of Control System in Large Audit Firms". Auditing: A Journal of Practice and Theory. Volume 15 No. 2. pp. 65-84.

Pendit, P. L. 2003. Penelitian Ilmu Perpustakaan dan Informasi: Sebuah Pengantar Diskusi Epistemologi \& Metodologi. Jakarta: JIP-FS UI.

Pierce, B. and Sweeney, B. 2004. "Cost-Quality Conflict in Audit Firms: An Empirical Investigation". Europan Accounting Review. Volume 13 No. 1. pp. 415-441.

Porter, L. W., Steers, R. M., Mowday, R. T., and Boulian, P. V. 1974. "Organizational Commitment, Job Satisfaction, and Turnover Among Psychiatric Technicians". Journal of Applied Psychology. Volume 59 No. 5.

Raghunathan, B. 1991. "Premature Signing-off of Auditor Procedure an Analysis". Accounting Horizon. Volume 5 No. 2. pp. 71-79.

Reed, S. A., Kratchman, S. H., and Strawser, R. H. 1994. "Job Satisfaction, Organizational Commitment, and Turnover Intentions of United States Accountants: The Impact of Locus of Control and Gender". Accounting, Auditing \& Accountability Journal. Volume 7 No. 1. pp. 31-58.

Rhode, J. G. 1978. "Survey on the Influence of Selected Aspects of the Auditor's Work Environment on Professional Performance of Certified Public Accountants". Issued as the Independent Auditor's Work Environment: A Survey, New York. American Institute of Certified Public Accountants.

Robbins, S. P. 2003. "Organizational Behavior: Concept, Controversies, Application". Seventh Edition. New Jersey: Prentice Hall Inc.

Rotter, J. B. 1966. "Generalized Expectancies For Internal Versus External Control Of Reinforcement". Psychological Monographs. Volume 80. pp. 1-28.
Setiawan, I. A. dan Ghozali, I. 2006. Akuntansi Keperilakuan: Konsep dan Kajian Empiris Perilaku Akuntan. Semarang: UNDIP Press.

Shapeero, M., Koh, H. C., and Killough, L. N. 2003. "Underreporting and Premature Sign-off in Public Accounting". Managerial Auditing Journal". Volume 18. No. 6/7. pp. 478-489.

Silaban, Adanan. 2009. Perilaku Disfungsional Auditor dalam Pelaksanaan Program Audit. Disertasi. Semarang: Program Pascasarjana Universitas Diponegoro.

Smith, W. R., Hutton, M. R., and Jordan, C. E. 1996. "Underreporting of Time: Accountants are Doing It More and Enjoying It Less". The CPA Journal. Volume 66 No. 10. pp. 67-70.

Sososutikno, Christina. 2003. "Hubungan Tekanan Anggaran Waktu dengan Perilaku Disfungsional serta Pengaruhnya terhadap Kualitas Audit". Simposium Nasional Akuntansi VI. Surabaya.

Sugiyono. 2001. Metode Penelitian Administrasi. Bandung: Alfa Beta.

Supranto, J. 1997. Metode Riset. Edisi Revisi. Jakarta: PT. Rineka Cipta.

Suryanita, Dody, Hanung Triatmoko. 2007. "Penghentian Prematur Atas Prosedur Audit". Jurnal Riset Akuntansi Indonesia. Volume 10 No. 1.

Trevino, L. K. and Youngblood, S. A. 1990. "Bad Apples in Bad Barrels: A Causal Analysis of Ethical Decision Making Behavior". Journal of Applied Psychology. Volume 75 No. 4. pp. 378385.

Umar, Husein. 2001. Metode Penelitian Bisnis untuk Skripsi dan Tesis Bisnis. Jakarta: PT. Gramedia Pustaka Utama.

Ulum, Akhmad Samsul. 2005. "Pengaruh Orientasi Etika Terhadap Hubungan Antara Time Pressure dengan Perilaku Prematur Sign-off Prosedur Audit". Jurnal Maksi. Volume 5 No. 2.

Weningtyas, S., Setiawan, D., dan Triamoko, H. 2006. "Penghentian Prematur Atas 
Prosedur Audit". Simposium Nasional Akuntansi IX. Padang.

Wijayanti, P. 2007. Pengaruh Karakteristik Personal Auditor Terhadap Penerimaan Perilaku Disfungsional Audit (Studi Empiris pada Auditor Pemerintah yang bekerja di BPKP di Jawa Tengah dan DI Yogyakarta). Tesis. Semarang: Program Pasca Sarjana Universitas Diponegoro.

Willet, C. and Page, M. 1996. "A Survey of Time Budget Pressure and Irregular Auditing Practices Among Newly Qualified UK Chartered Accountants". British Accounting Review. Volume 28. pp. 101-120.
Wilopo. 2006. "Faktor-Faktor yang Berpengaruh Terhadap Perilaku Disfungsional Auditor: Studi Pada Kantor Akuntan Publik di Jawa Timur". Akuntansi dan Teknologi Informasi. Volume 5 No. 2. pp. 141-152.

Zahra, S. A. 1989. "Executive Values and the Ethics of Company Politics: Some Preliminary Findings". Journal of Business Ethics. Volume 8. pp. 15-29.

http://id.wikipedia.org/wiki/Komitmen_organisa si

http://matramuda.blogspot.com/2011/02/perilak u-manusia.html

http://necel.wordpress.com/2009/06/28/pengerti an-prosedur/ 